\title{
Court interpreting in the United Kingdom: analysis of the Ministry of Justice's Language Service New Contract
}

\author{
Aurora Ruiz Mezcua \& Alicia Fernández Gallego-Casilda \\ Universidad de Córdoba \& Traductora profesional \\ aurora.ruiz@uco.es \& afgc89@gmail.com \\ https://dx.doi.org.10.12795/futhark.2016.il I.10
}

Fecha de recepción: 13.03.2016

Fecha de aceptación: 15.04.2016

Abstract: Court interpreting is a challenging context where languages are fundamental to ensure justice and respect for human rights. The phenomenon of public service interpreting is a relatively recent one and the UK is considered to be one of the pioneer countries in providing Community Interpretation. The main objective of this research is to analyse the diverse aspects of the contract signed by the MoJ in 2012 with a private company for the outsourcing of language services. The MoJ previously obtained such services from freelance interpreters through a different system. We study the reasons for changing the old Ministry of Justice language service contract, the transition and also the new system, from an interpreting quality perspective. Consequently, this paper concentrates on one hypothesis: that there are elements in this outsourcing contract that pose a risk to the quality of the services provided under it.

Key words: court interpreting, interpretation, ministry of Justice, language services, community interpreting.

La interpretación judicial en Reino Unido: análisis del nuevo contrato de servicios lingüísticos del Ministerio de Justicia británico

Resumen: La interpretación judicial es un ámbito de cierta complejidad donde los idiomas son fundamentales para asegurar el cumplimiento y respeto de los derechos humanos. El fenómeno de la interpretación social es relativamente reciente y Reino Unido se considera uno de los países pioneros en ofrecerla. El principal objetivo de esta investigación es analizar los distintos aspectos del 
contrato firmado por el Ministerio de Justicia de R.U. en 2012 con una empresa privada encargada de proporcionar dichos servicios. El ministerio antes obtenía ayuda lingüística mediante un sistema diferente. En este artículo estudiamos las razones por las cuales se cambió el anterior contrato para la prestación de servicios lingüísticos, la transición entre ambos y la puesta en marcha del nuevo sistema desde la perspectiva de la calidad de la interpretación. De este modo, nos concentramos en una hipótesis principal: parecen existir elementos en el contrato de externalización que suponen un riesgo para la calidad de los servicios que proporciona.

Palabras clave: interpretación judicial, interpretación, ministerio de Justicia, servicios lingüísticos, interpretación comunitaria o social.

Sumario: I. Introduction. I.I. State of the Art: Public service interpreting: a brief overview. I.2. Methodology. 2. The Moj's old language service contract. 2.I. The reason for the change of system. 2.2. Preparations for transition of the new system. 3. The new system: Main changes introduced and implementation. 3.I. Recruiment of interpreters. 3.2. Early and later operational difficulties with demand. 3.3. The Ministry's response and subsequent advancements. 4. Compliance with quality standards: an analysis. 5. Results. Conclusions.

\section{Introduction}

\section{I.I. State of the Art: Public service interpreting: a brief overview}

The globalisation process defining contemporary societies is undeniable: culture abandons its watertight geographical space as a result of constant loans and exchanges. In Europe, the increasing unregulated immigration from non-EU has intensified sociocultural diversification, together with the opening of borders through the creation of the Schengen area in 1995 which "represents a territory where the free movement of persons is guaranteed" (EurLex, 2009: online).

An intrinsic feature of this growing variety is the communication need of both linguistic and cultural nature which arises in multiple contexts. The concept of "social interpreting" or "community interpreting" consequently comes to be, referring to the activity of mediation between languages and cultures to allow the foreign immigrant population to make use of the public services available in the receiving community. This practice has been shaped as a form of social intervention and its contribution to integration is essential:

Community interpreting enables people who are not fluent speakers of the official language(s) of the country to communicate with the providers of public services so as to facilitate full and equal access to legal, health, education, government, and social services (Carr, Roberts et al. 1997: 21). 
The phenomenon of public service interpreting is a relatively recent one, with a dissimilar level of development in different countries. In some regions, due to social, political or historical circumstances, considerable progress has been made in the path toward the professionalisation of the work of community interpreters. These circumstances include, among others, the historical receipt of large volumes of foreign population or institutionalised bilingualism. As such, community interpreting is a thoroughly consolidated practice in places such as Australia, Canada and Sweden, with training and regulation mechanisms. Australia is in fact regarded as "the most advanced country in this field, in terms of professionalization, accreditation and training” (Íbid.).

In the United Kingdom, the country on which this article focuses, it is only in the 90s when the term "public services interpreting" is coined to describe the practice facilitating communication between public authorities and different groups of individuals when the latter do not understand the language or languages in which such authorities offer their services (D'Hayer, 2012: 235-247). The evolution of translation and interpreting in public services in the United Kingdom is marked by the establishment in 1994 of the NRPSI (National Register of Public Service Interpreters), in which the interpreters are accredited by the Institute of Linguistics. This record covers, among others, both the legal and health sectors and is characterised by its strict criteria for entry. The Register also requires compliance with its own code of professional conduct with the aim of maintaining a certain standard of quality within the public services.

The trajectory of court interpreting, in particular, is characterised by its lack of recognition and regulation as an activity, with numerous gaps in terms of training and experience requirements for its praxis and with regard to the role of court interpreters in different contexts in which this service is used. As reported by the Association Internationale des Interprètes de Conférence (AIIC, International Association of Conference Interpreters) in a communiqué, the situation up to date is as follows:

Court and legal interpreting throughout Europe had often developed sui generis, without training or regulation, contrary to its sister practice of translating where many countries require certification. Very often legal translators are called upon to act as interpreters. Their "certification" as translators is often confused with recognition of their skills as interpreters, which may not be comparable (Justice Committee, 2013: online).

It is a relatively emerging practice, in spite of trials with interpreting services in 1682 and 1829 recorded by authors such as Colin and Morris, which represented a turning point for English jurisprudence (Mikkelson 1996: online). In 2010, nevertheless, the European Directive 2010/64/EU of the European Parliament and of the Council on the right to interpretation and translation in criminal 
proceedings appears. The Directive established the 27th October 2013 as the deadline for transposition into the national legislation of each Member State. The publication of this legislative tool, which sets out rules in the context of criminal proceedings and European arrest warrants, is based mainly on article 6 of the European Convention for the Protection of Human Rights and Fundamental Freedoms, which explicitly states the right to a fair trial as indicated in the Directive itself. Section 14 of the Directive, on page two:

The right to interpretation and translation for those who do not speak or understand the language of the proceedings is enshrined in Article 6 of the ECHR, as interpreted in the case-law of the European Court of Human Rights. This Directive facilitates the application of that right in practice. To that end, the aim of this Directive is to ensure the right of suspected or accused persons to interpretation and translation in criminal proceedings with a view to ensuring their right to a fair trial (European Directive 2010/64/EU, section 14).

We are yet to see the positive transformations that putting into practice these rules of European Community law will bring about going forward. The truth is that, so far, the lack of legal texts of this kind has resulted in the field of public service interpreting in general, and of court interpreting in particular, in a reigning chaos which has fostered the disregard of how crucial it is to employ adequately trained and experienced professionals in this area. In the words of Martin and Abril Martí:

Sólo un intérprete seguro de su papel como facilitador de la comunicación y cuya conducta inequívoca ofrezca las necesarias garantías de imparcialidad y confidencialidad obtendrá la confianza de ambas partes en su actuación. Y esto, a su vez, fomentará el respeto hacia la interpretación como profesión" (Martin et al. 200I: 55-60).

It is only this way that we can safeguard the respect for human rights and achieve a proper functioning of the system for the users of these particular services without incurring in additional expenses resulting from precarious praxis. Rutherford, a journalist for the Belfast Telegraph, narrates for instance how the cost for a rape trial involving two Lithuanian men rose to $£ 30,000$ when cancelled after a day due to concerns about the accuracy and veracity of the interpreting services offered (Rutherford, 2014: online).

According to Mateo Alcalá, the lack of regulating mechanisms for the function of public service interpreters, which applies also to court interpreters, generates the consolidation of this career as a non-professional practice carried out mainly by volunteers (Mateo Alcalá, 2004: online). This circumstance shows to what extent the institutions and the Administration of multiple countries do not 
fully comprehend how vital this profession is in the health, education and legal sectors, among many others. The author expresses it as follows:

Esta circunstancia hace que la posibilidad de la profesionalización de una actividad que cuenta con personas formadas, personas que han realizado estudios de interpretación, se aleje mientras exista un voluntariado que la ejerza. (Sin menospreciar la actividad que realizan estos voluntarios que en muchas ocasiones es elogiable.) (Mateo Alcalá, 2004: online).

The evidently insufficient recognition of public service interpreting results in witnessing events that would be avoided if there were relevant regulations in place, or which would occur in a more controlled manner. An example of these events is that which constitutes the subject of study of this research work: the privatisation of court interpreting services which took place in the United Kingdom at the beginning of 2012. In August 20II, the MoJ signed a four-year framework agreement with a private company outsourcing translation and interpreting services (National Audit Office, 2012: 4).

Until then, courts in England and Wales hired freelance interpreters through the previously mentioned NRPSI. This private company promised, as Bell (a journalist for $\mathrm{BBC}$ News) describes in an article, to reduce by a third the annual expenditure of $£ 60$ million of the MoJ in translation and interpreting (Bell 2012: online). In another article from the same source, whose author's name is not explicit, it is documented that the MoJ did not have a complete understanding of the intricacies surrounding court interpreting when they put these services out to tender and made a final decision from all candidate companies.

\section{I.2. Methodology}

Since this work is centred on the outsourcing contract for language services signed by the Ministry of Justice with a particular private company, some information about the tender and implementation processes has also been obtained from the so-called Freedom of Information (FOI) Request documents. Through these requests, citizens are allowed to request public authorities to disclose particular information, and the responses provided are publicly available online. A number of requests of this sort answered by the MoJ have been used to verify much of the information collected. In addition to the FOI documents, reports of public access issued by the MoJ itself and other British public authorities and official institutions, such as the National Audit Office (which scrutinises public spending in the United Kingdom on behalf of the Parliament) have been used to gather relevant information on the implementation and performance of the system for the supply of language services to the different forces of the MoJ.

Besides, there is first-hand information in this piece of work. Several professionals in the field have been contacted in pursue of further information. 
María Isabel Abril Martí, lecturer at the University of Granada, has helped via email with her professional knowledge of public service interpreting and her involvement in research on quality in this field. Other experts contacted include Anne Martin (from the University of Granada) and Matthew Perret (University of Leeds), who provided good advice and directed me to useful reference materials on the topic of this research work. We were also in touch via email with Berrin Golding, a Turkish interpreter who resides in Manchester and has worked as a public service interpreter for the Mol both under the old and the new system. She was most helpful in allowing us to understand and confirm much of the information we were reading through.

Finally, the objectives of this work have been achieved mainly through the collection of information from reference articles on the topic of public service and court interpreting. The documentation material used deals with this topic from different perspectives, focusing on aspects such as the evolution of the profession, its current situation, the quality of the services provided through its practice or the procurement arrangements made by public authorities to provide interpretation services.

\section{The MoJ's old language services contract}

To understand the gaps of the new system established by the call for tender of the MoJ it is necessary to know the main aspects of the preceding system. Until January 2012, the MoJ hired most interpreters through the previously mentioned NRPSI. Hiring was carried out by the judicial staff individually, while tribunals used a slightly different system: a panel of interpreters and a central team organising interpreting assignments and carrying out the corresponding payments (The Ministry of Justice's language services contract. National Audit Office, September 10th, 2012: 8). A vast amount of these interpreters were also included in the NRPSI. The professionals listed in this register theoretically needed to have the required qualifications and accreditations, as well as a Criminal Records Bureau (CRB) check. Both the NRPSI and the panel of interpreters used by tribunals offered the MoJ certain guarantees about the quality and reliability of the interpreters through the qualification and professional experience requirements, as well as through demanding compliance with the professional code of conduct. Besides, the NRPSI charged interpreters $£ \mid 30$ for annual membership.

The main criteria for entry into the NRPSI was then and is still holding the Diploma in Public Service Interpreting (DPSI), granted in different specific areas of the public sector in which translation and interpreting services can be provided: Scottish law, English law, health and local government. The exam to obtain the DPSI is divided into five modules which include consecutive and simultaneous 
interpreting, sight translation both from and into English and finally, written translation in both linguistic directions. In the case of rare languages, however, this exam does not take place, and there are other criteria in place for entry into the NRPSI such as previous professional experience, although yearly assessments take place. $^{1}$

\section{I The reasons for the change of system}

The old system was a consolidated one, well-known to the staff using it, but it proved ineffective for multiple reasons. For example, courts hired and paid interpreters separately, and each court devoted their own stuff to hiring interpreters. The cost of this aspect of the old system in terms of time invested was not really visible to the HM Courts and Tribunals Service (HMCTS). On occasions, the relevant staff were even unable to find an available interpreter through the system, or ignored the procedure by which they were meant to consult the NRPSI first of all. In consequence, some interpreters working for the Mol had not had their qualifications or CRB check verified. In these cases, it was rather tedious and difficult for the MoJ to discard these interpreters when there were problems with the quality of the service provided. However, the advantage of the local nature of the system was that each court or tribunal knew what interpreters to avoid as a result of negative past experiences.

Similarly, under the old system, some courts were making use of outdated copies of the NRPSI. There also was a complete absence of centralised management of the necessary and available linguistic services, meaning that courts and tribunals were not entirely aware of the demand for certain languages or of the quality of the interpreting services supplied in the different branches of the system. This situation resulted in a shortage of interpreters in some of these judicial institutions. Between 2010 and 201 I, for instance, 18 Crown Court cases and 373 magistrates' court cases were ineffective due to problems relating to interpreting (The Ministry of Justice's language services contract: 10).

In short, there were enough reasons for the MoJ to want to transition to a new system, from which the most decisive ones were the systematic inefficiencies of the old system and the reduced reliability of the interpreters for some particular languages. Thus, during 2009, the MoJ and some other institutions carried out an assessment of the functioning of the language services system in place in the judicial sector, with help from the Office of Criminal Justice Reform. This judicial institution drafted a report that, together with the audit carried out in 2010 by the HMCTS,

\footnotetext{
1 "Diploma in Public Service Interpreting: Handbook for Candidates", Chartered Institute of Linguistics, last $\quad$ updated October 2015 , https://www.ciol.org.uk/images/Qualifications/DPSI/DPSI\%20Handbook\%20Oct-I5.pdf.
} 
highlighted the flaws of the system and the need for the Mol to seek a new system resulting in a higher number of interpreters available, better quality, less expenses and greater efficiency.

As a result, "in early 2010, the Ministry set out to change the way that interpreters were procured to increase the availability and quality of interpreters; to save money by making the booking and payment of interpreters more efficient and reducing payments to interpreters; and, allow it to collect management information on interpreter usage and cost". ${ }^{2}$ Consequently, the MoJ decides to launch this call for tenders to outsource translation and interpreting services, which are mostly used in courts, tribunals, probation centres and prisons (The Ministry of Justice's language services contract": 7). The process expanded from September 2010 to August 201 I. Of I 26 potential suppliers registered, only 58 submitted the required pre-qualification questionnaire for evaluation, and the MoJ selected 12 to actually participate in competition based on service, assurance of supply, quality, innovation and sustainability.

Finally, a four-year framework agreement was signed with that single private company to cover translation and interpreting services all across the justice sector. In accordance with this agreement, the MoJ and said company also signed a fiveyear contract, which represents the main subject of study of this research work. The contract came fully into force on 30 January 20I2, and it was estimated at $£ 90$ million. From this total, around $80 \%$ ( $£ 70$ million) corresponds to translation and interpreting services for the HMCTS. The value of the framework agreement itself was estimated at $£ 168$ million (Íbid.).

\subsection{Preparations for transition and implementation of the new system}

With the cost-saving parameter in mind, the Mol estimated its different forces to save up to $£ \mid 8$ million a year in payments to interpreters, and to increase efficiency through lesser administration work. In terms of rolling out the new system, up until October 20II the MoJ planned to carry it out on a regional basis and in several phases for courts and tribunals, and for the police forces as well. However, the Mol eventually decided in favour of a single implementation stage at a national level, which was referred to as a "big bang" strategy at the time (Íbid.). As a precautionary measure, an implementation test took place first in the North West region in December 20I I, leading to the global go-live on 30 January 2012.

From their point of view, the regional implementation strategy posed a smaller risk for the MoJ in this area of business because:

2 "Statistics on the use of language services in courts and tribunals: Statistical bulletin 30 January 2012 to 3 I January 20I3", Ministry of Justice, March 28, 20I3: 7. 
- it would have allowed the Ministry to limit the effect of poor performance or other 'teething troubles' to a subset of regions and tribunals, and also to pause the rollout if performance was very bad; and

- it would have given the Ministry better information about the type and volume of languages actually required in the system, something which it still did not know (Op. cit. 14).

Everything seemed to suggest that this single, national implementation would not be successful. As a matter of fact, the Office considers that even with the regional approach, further delay in the process would have been desirable. As it has been mentioned right before, many interpreters were trying to put the message across to the MoJ that they would not agree to the new outsourcing arrangements. At the same time, the supplying company itself showed concerns to the Ministry as they faced difficulties to recruit a sufficient number of interpreters to meet the demands of all courts and tribunals involved. Nonetheless, the company went ahead with the national rollout despite knowing they lacked the resources to fully support the process.

This approach to adopting the new system did not constitute a true representation of the ability of the supplying company to deliver on a larger-scale, because of the following reasons: it was the area where the company was based, it presented the highest number of interpreters working for the company, and it accounted for most of the supply required under the previous public sector contract. In addition, the implementation in the North West took place during Christmas and New Year, which is one of the quietest periods for the industry.

\section{The new system: Main changes introduced and implementation}

The main alterations to the old system introduced by the Ministry of Justice's language services contract are listed below. For the purposes of this article, the following quote is slightly amended to avoid any explicit mention to the company's name supplying translation and interpreting services to the $\mathrm{Mol}$ in the justice sector under the new system (The Ministry of Justice's language services contract: $\mid \mathrm{I}-12)$ :

- The company [sic] proposed a tiered approach. The justice sector would book interpreters who had the right level of skill for each job. Lower-skilled workers, who had not been eligible to register with NRPSI but who might still have done justice work, would attract a lower fee.

- The company [sic] set interpreters' pay and conditions under the new system, and would be free to vary these at any time (the amount the 
Ministry paid to the company [sic] for the work would not change). The assumption about remuneration on which the company [sic] bid, and which it subsequently tried to implement in January 20I2, involved a cut in interpreter pay and benefits in real terms.

- The company [sic] would create a website, the portal, through which all bookings would be placed by court and other staff, with responsibility for the subsequent sourcing and paying of interpreters resting entirely with the company.

- To address quality concerns, the company [sic] would implement a robust complaints procedure and also proposed introducing a mandatory assessment for interpreters to pass before working on the contract, irrespective of pre-existing qualifications.

- Through centralisation, the Ministry understood that the company's [sic] proposal, in common with all others, would improve its access to management information about its language needs.

In terms of payment to interpreters, the most noticeable changes were the eradication of minimum daily payments for all three tiers of interpreters and the lack of travel time payments during weekdays. As for weekends, travel time payments do not occur for total return journeys under two hours. It must be noted, however, that in order to encourage the use of the online booking portal, a $£ 5$ supplement per online booking was offered to interpreters as an incentive.

\section{I. Recruitment of interpreters}

At the outset of the national rollout for the new language services system, many interpreters working under the old arrangement declared their refusal to supply any services under the outsourcing contract introduced by the MoJ. As a consequence, the Ministry needed to determine how many suppliers would still be available and willing to provide interpreting services, since they estimated their need at around I,200 to cover the existing demand.

The eligibility of an interpreter under the framework agreement was based on whether the company could: "collect evidence of their qualifications, experience and Criminal Records Bureau disclosures and verify that evidence; assess and mark the interpreter using their new assessments; and assign them to one of three tiers" (The Ministry of Justice's language services contract: 17). By mid-January 2012, when a final decision had been made in favour of a national rollout of the new system, it became fairly clear that the supplying company would be unable to comply with the second action point established as presented above. As a result, "the contract became operational with a large number of interpreters who had not passed a mandatory quality requirement" (Íbid). In the face of this expected shortage of interpreters and other subsequent problems, the MoJ did not properly warn all the 
different forces it was meant to supply interpreting services to. If they had come to know, it is likely that many of these forces would have requested to revert to the old system.

\subsection{Early and later operational difficulties with demand}

Problems under the new contract started occurring immediately after the implementation process started in January 2012. Courts and tribunals struggled with both the supply of interpreters for requests in certain languages and the quality of the interpretations provided. For the first two months following the golive of the contract, its performance was rather inadequate, causing the different forces of the MoJ to miss targets and have to turn to old arrangements to complete part of the interpretation work demanded. $58 \%$ of bookings were met in February and $73 \%$ in March.(Op.cit. 24). These percentages, however, are not a true representation of the performance for this period in 2012. This is due to the fact that some of the assignments registered as "cancelled" by the supplying company had not occurred in the first placed because the company had been unable to provide a suitable interpreter.

One particularly problematic aspect of the early stages of functioning of the new contract was covering for short-notice work. The Mol lacked sufficient information about the old system to provide its new interpreting services supplier with a good estimation of "the volume of interpreters likely to be ordered at less than 24 hours' notice"(Op.cit.:2I). This affected namely the magistrates' courts, and was also applicable to extradition hearings. The consequences of these issues were rather disruptive, with a different degree of damage in the several spheres of the justice sector.

In the first place, in the case of magistrates' courts, 182 trials were ineffective due to supply shortages in the first quarter of 2012. This amount represented "double the number recorded for the same period" in 2010, with 95 ineffective trials at magistrates' courts (Op.Cit.: 24). Secondly, the HMCTS found it hard to handle the workload resulting from the transition to the new system. Their staff invested too much time arranging bookings through the supplying company's online portal, which did not work appropriately. Subsequently, old local methods to book interpreters were still often used. We cannot overlook, in the third instance, the costs that the MoJ will likely have incurred as a result of the numerous delays experienced by the HMCTS and others involved in the legal processes. Whilst it is very difficult to place a monetary value on these costs, the Mol has given an approximate opportunity cost of $£ 60,000$ for the months of February and March 
2012. ${ }^{3}$ The MoJ has accepted the total opportunity cost of the delays will exceed this figure.

\subsection{The Ministry's response and subsequent advancements}

In view of the problems described, such as inefficient trials and multiple complaints, the Ministry decided to react to the detrimental effects that poor performance under the new contract could potentially have in the long-run. As a first resort, the MoJ allowed courts and tribunals to source interpreters via old methods when needed. This contingency measure had already been considered by the MoJ before implementation, as guarantee of coverage for short-notice work. Some tribunals, in fact, returned fully to the old booking system from February onwards, such as those for immigration and asylum. In these institutions, there is often urgency for supply within less than $\mathbf{4 8}$ hours.

Besides, the MoJ started holding regular meetings with the supplying company and started requesting daily performance updates. Further to this, as a result of their continued dissatisfaction, they called senior management of the company to action to solve problems relating to supply, the online portal and the lack of response and feedback to courts and tribunals over unfulfilled requests. What is more, the MoJ even threatened the Chief Executive Officer of the company to terminate the contract in February 2012 if there were no imminent improvements. The main action points carried out by the supplying company in reaction to the Ministry's ultimatum were (Íbid.:26):

- $\quad$ increasing pay and benefits for interpreters, so that (...) the average drop in remuneration over the old system reduced from 20 per cent to 8 per cent;

- $\quad$ replacing a number of senior managers;

- recruiting more staff for the service centre and restructuring it so that team members were responsible for specific courts and languages; and

- providing an additional server for the portal.

However, it was not only on the part of the supplying company that change was required. The Justice Committee of the Parliament of the United Kingdom posed a series of challenges to the MoJ about their own performance in the signing off of the framework agreement and subsequent transition from the old to the new

\footnotetext{
3 The MoJ came up with this amount when analysing several areas of inefficiency within its functioning, on the basis of multiple data from the justice sector as referenced in "The Ministry of Justice's language services contract": 25 .
} 
language services system. ${ }^{4}$ The MoJ responded to such challenges in a government publication in April 2013, grouping its replies by recommendation category. ${ }^{5}$

Under "Proving the capability of the Framework Agreement", for instance, the Justice Committee's main statements were that "the MoJ audit the true amounts that are being expended on interpreter pay and travel" by its supplier and that the MoJ and the supplying company itself "must prove that the Framework Agreement (FWA) is capable of attracting, retaining and deploying an adequate number of qualified and competent interpreters". 6

In response to this, and in line with some of the action points listed above, the terms and conditions of the FWA were amended to address all these different issues and "to better reflect the expenses that interpreters might incur through their work and provide an overall remuneration package that will attract and retain interpreters". The MoJ also committed to monitoring the results of these measures and discuss further developments.

As for "Quality of interpreters", the Justice Committee supported the National Audit Office's requirement that the tiered system should be independently evaluated. Also, the Committee pushed for the avoidance of tier 3 interpreters in courts and tribunals unless absolutely necessary (for rare languages, for example).

The MoJ, in turn, reported the initiative to identify a "suitable independent person" to undertake such assessment under the FWA. They also reported their expectation that the changes to the terms and conditions of the Agreement would "increase the number and availability of Tier $\mathrm{I}$ and Tier 2 interpreters and therefore reduce the need to use Tier 3 interpreters". Furthermore, they reiterated that when the supplying company was unable to provide a Tier I or Tier 2 interpreter, the use of a Tier 3 interpreter was ultimately at the discretion of the court or tribunal, and the judge dealing with the case. Finally, they added that they reserved themselves the right to make "some sensible exceptions to the qualification standards" so that some of the interpreters who had been working successfully in the justice system under the FWA could easily enter Tier 2.

To finish with, other recommendations to which the Mol responded (although less relevant for this research work) concerned the handling and supply of "Performance data" and the management and reporting of "Cost savings". The

\footnotetext{
4 The Justice Committee is appointed by the House of Commons and it examines expenditure, administration and policy of the Ministry of Justice and other associated public bodies.

5 "Government Response to the Justice Committee's Sixt Report of Session 2012-13", Ministry of Justice, May 2013.

${ }^{6}$ Ibid., 4.
}

Futhark II (2016) 
latter applied mainly to cases that had been repeatedly adjourned as a result of interpreting problems and for which there was no record of the administrative costs incurred.

The fruits of the control mechanisms and corrective measures put in place by the MoJ remain to be seen in due time. In the short-tem, however, following to the joint efforts of the Mol and its supplying company, the operation of the new system improved significantly.

In September 2012, the company was successfully fulfilling a $98 \%$ of interpreter bookings on some days, whereas the average rate was of $95 \%$. It cannot be overlooked, in any case, that this percentage excludes around 15\% of court and tribunal work which remains functioning under the old arrangements. On another note, just over $4 \%$ of 12,000 bookings in July that year resulted in complaints. Although complains from courts are tribunals are still frequent, the Mol now monitors them thoroughly to identify trends and to tackle them appropriately (The Ministry of Justice's language services contract: 26-27).

In terms of supplier management, the interpreters themselves can now enter their working hours on the portal when the HMCTS staff fails to do so within 48 , so that payment delays are avoided. To counter the potential lack of financial control of this portal functionality, the MoJ claims to be currently designing a control procedure for this purpose.

\section{Compliance with quality standards: an analysis}

The discouraging scenario in some countries in relation to translation and interpreting in public services leads to a reflection on the criteria governing the hiring of professionals and, as a result, the quality of the services provided and the control mechanisms established for their professional praxis. Although it is a reasonable hypothesis that this lack of professionalisation can have negative effects on quality, it is difficult to offer a clear and precise definition of the notion of quality.

From a commercial point of view, not even international norms on the matter currently in place achieve such a definition (ISO 9001:2008, for instance). In an academic context, different authors have gathered criteria on which to base the quality of the interpreting services provided. Among these parameters we can find fidelity and integrity of the interpretation, the voice and accent of the interpreter and terminological accuracy (Collados Aís and Gile, 200I: 312-326). Other definitions state that quality in interpreting ought to be considered as a service as well, not merely a product (Pöchhacker, 200I: 4I0-425). 
Quality is, in short, a subjective concept defined by what is agreed upon by the party offering a particular service and the party receiving such service, in relation to this latter party's needs and expectations. As such, the degree of quality can vary considerably based on the parties involved, the service in question or the goal to be achieved, among others (Ortega Herráez, 2013: 12).

The quality criteria governing a particular outsourcing process for language services can be determined by what a particular authority considers to be an acceptable standard of quality. The specifications contained in calls for tenders for interpreting services are therefore a representation of the conceptions of the Administration regarding the role of interpreters and the quality of service they must provide.

We can identify four main parameters which can directly affect the quality of any interpreting service provided under an outsourcing agreement for language services: professional qualification of the interpreters, continuous training, interpreting technique applied and compliance with professional ethics. Analysing the Mol's new language services contract against these parameters can help us determine the expected quality of the public service translation and interpreting services provided under such outsourcing agreement. It is also necessary to consider an additional factor: what control tools are in place as a complement to contracts of this kind to guarantee their effective functioning?

This analysis will allow us to recognise the deficiencies and gaps in such contract and, in consequence, distinguish to what extent the quality of the services provided to citizens is at stake under the new system.

An adequate academic and professional background is, by all means, an essential criterion when establishing quality standards for the supply of interpreting services. Therefore, it is of the utmost importance to examine the qualification and certification requirements included in any outsourcing contract by which these services are provided.

In general, most calls for tenders explicitly specify the level of professional qualifications that the interpreters have to comply with if the contract in question is to be executed with a particular company. However, on certain occasions these specifications are rather vague and can say nothing more than the interpreters ought to have "sufficient knowledge" of the field (The Ministry of Justice's language services contract: 17). This relatively lenient attitude in the inclusion of qualification criteria for interpreters in outsourcing contracts can make us question the quality of the services provided under such contracts.

The contract we are examining in this research work complies with the aforementioned specifications to varying degrees on the basis of the tier in 
question. For Tier I interpreters in particular, a full DPSI in the field of English law as previously described is one of the several entry options, and it constitutes the most common one. ${ }^{7}$ A CRB check is also carried out for these interpreters, as mentioned before.

Other options for listing under this tier include the Certificate in Community Interpreting. There are different levels for the granting of this certificate, the most widely recognised one being "Level 3". The rest of entry options vary from NRPSI registration to membership to the Institute of Translation and Interpreting ("Police Court Interpreter" level).

We can therefore corroborate that, for Tier I interpreters in particular, who are vastly used under the Moj's language services contract, the requirements for interpreters in terms of qualifications are significantly precise. This allows us to assume that a minimum quality standard is to be preserved through these qualification criteria. In the case of Tier 2 interpreters, who are significantly used, and of Tier 3 interpreters, the qualification criteria are not as strict and the gap with the requirements for Tier $\mathrm{I}$ interpreters is rather acute. Tier 2 offers interpreters the possibility to substitute the need for a partial DPSI plainly for certain English d language-related degrees and diplomas. As for Tier 3, applied mostly to rare languages, there is only need for some basic interpreting training or previous experience in the sector combined with a linguistic background.

When it comes to professional experience, however, the criterion is homogenous among all three tiers: 100 hours interpreting experience in the public sector; the only difference being that this requirement is mandatory for Tier I and Tier 2, and only desirable for Tier 3 interpreters. This adds up to the quality standard that can be expected of the interpreting services provided under this contract. The possible lack of quality deriving from the use of Tier 3 interpreters is in any case a necessary concession to be able to cover for some of the languages demanded by the MoJ.

As for ongoing training, this parameter is directly linked to the quality of the interpreting service provided: it allows the interpreters to respond and adapt to the many and rapid changes which can occur in any professional field (Ortega Herráez, 2013: 20).). As a matter of fact, ongoing training constitutes a crucial element within many professional accreditation systems. Some of these require interpreters to attend seminars and conferences compulsorily in order to undertake certain examinations or to preserve their membership status. An example of a system of this kind is the previously mentioned National Accreditation

7 Tier 2 interpreters are only required a partial Diploma in Public Service Interpreting in the field of English law: they do not have to undertake the exam consisting of a written translation from English. 
Authority for Translators and Interpreters (NAATI), in Australia. The interpreters registered with NAATI ought to comply with the AUSIT Code of Ethics and Code of Conduct, established in 1987, which requires them to commit to lifelong learning. ${ }^{8}$

This is a clear gap in the Moj's language services contract, as the FWA signed with the supplying company includes no explicit mention to the need for ongoing training on the part of the interpreters it registers to provide services within the justice sector. Hence, this is one particular area in which this contract displays a field for a potential downgrade of quality and which can be studied and developed in future investigations.

When it comes to interpreting techniques, the most widely used interpreting mode in judicial and police settings is consecutive interpreting in its dialogical form, followed by sight translation and finally whispered simultaneous interpreting or chuchotage (Ortega Herráez, 2013). The reason for the predominance of liaison interpreting is the fact that it allows full participation on the part of the accused or suspected person in court and police interpreting. This, in turn, can be considered to guarantee a certain level of fairness of the proceedings for the person involved and, consequently, a certain quality standard. However, simultaneous interpreting in booths is purposely used in some cases (hearings, for instance) to make the proceedings smoother.

Examining the Moj's contract in this respect highlights the fact that the listing of language services offered is somewhat vague. When "telephone interpreting" is mentioned, we can unmistakably assume that the interpreting technique used will be dialogue interpretation. When the contract refers to "face-to-face interpretation", on the other hand, we can take for granted the same assumption but we do not have the certainty whether this excludes simultaneous interpreting.

In any case, the inclusion of other modes of language service other than interpreting (such as sign language interpreting, translation and sight translation services when applicable) is an encouraging feature of the Moj's contract. An exclusion of certain techniques in the supply of language services could be in conflict with professional ethics.

Focusing on this last concept of compliance with a code of ethics, it usually represents an additional requisite to safeguard their membership and accreditation to such institution. An example of this sort of professional body is the NRPSI in the United Kingdom, which supplied interpreters to the MoJ prior to them signing off an outsourcing contract with a private company. All interpreters listed under the

8 AUSIT was founded in 1987, when the National Accreditation Authority for Translators and Interpreters (NAATI) called practitioners, educators and government language service provider representatives from around Australia to a meeting in Canberra to establish a national professional association. 
NRPSI are subject to adhering to their Code of Professional Conduct, and may be investigated if a breach of the Code is detected or suspected. ${ }^{9}$ The clauses of these codes can vary greatly from one call for tender to another, although they often focus mainly on confidentially on the part of the interpreters through nondisclosure agreements. This is a rather self-involved specification on the part of private companies supplying language services, which seeks to preserve their own interests instead of quality and ethical standards.

Although not explicitly included in the documents and reports we have been able to consult, it can be confirmed through personal experience that the company supplying language services to the MoJ requires their translators and interpreters to sign non-disclosure agreements, as well as terms and conditions.

\section{Results}

The findings of this analysis are contained in the chart below, which pictures the presence or absence of the aforementioned parameters within the contract signed by the MoJ for the supply of language services. The criteria displayed in green are those met by the Moj's outsourcing contract, whereas the absent parameters show in red:

\section{Quality parameters}

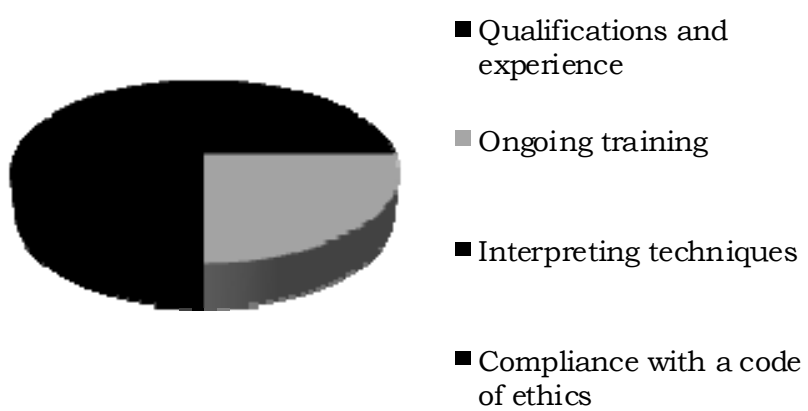

Legend

Black - Compliance with quality parameter

Grey - Non-compliance with quality parameter

9 "Code of Professional Conduct", National Register of Public Service Interpreters, last accessed January 24, 2016, http://www.nrpsi.org.uk/for-clients-of-interpreters/code-of-professional-conduct.html. 
This graphic allows us to appreciate, at a glance, that the overall content of the MoJ's language services contract is favourable toward quality standards. Out of the three quality parameters listed beforehand, this contract meets three of them $a$ priori.

The data exposed in this chart, however, needs to be considered in context. As we have previously explained, the level of compliance with some of these parameters is vague. In the case of the requirement for professional qualifications and previous working experience, for instance, we have seen how this applies fully only to Tier I interpreters under the MoJ's outsourcing contract. In the same way, when it comes to interpreting techniques, the contract hints at the predominant use of dialogical consecutive interpreting. This information is nonetheless not confirmed.

In view of how lax some calls for tenders can be in terms of quality criteria when it comes to translation and interpreting for public services, we inevitably wonder what control mechanisms are put in place by the relevant authorities to ensure that such specifications are respected efficiently. It is really of no use that a call for tender includes strict requirements for suppliers under their contracts if such documents do not also establish the necessary tools to guarantee that those requirements are met.

When it comes to professional qualifications, for instance, the vast majority of calls for tenders require very specific skills and formally-acquired knowledge from the candidate linguists. However, how can we know whether the private companies in question truly verify the qualifications of their suppliers? As this research work proves when documenting the implementation of the Moj's new language services system, this is not always the case. And what is more, when the authorities sign off agreements with private companies for the supply of language services, they often do not check whether such companies hold quality management certificates (such as the EN-15038: 2006, the European quality standard applying explicitly to translation services). ${ }^{10}$

\section{Conclusions}

The main conclusion from this research work is the remarkable lack of professionalisation surrounding court interpreting. The absence of recognition of this practice as a profession derives from several factors. These include insufficient training, disregarding the importance of association, the lack of codes of ethics for practising professionals and deficient legislative support. As a result, on many

10 This certification does not apply, however, to interpreting services. 
instances the need for specific skills to provide this service is disregarded and anyone speaking a foreign language is allowed to perform as an "interpreter". As it can be expected, the difference in performance is significant.

Regarding the contract that has been the object of this paper, AllC believes that the monopoly over this service generated by outsourcing, in which control over quality on the part of professionals and the MoJ has faded, has set under judgement the reputation of British Justice in the light of the European Directive 20/0/64/EU. Bell adds that since the MoJ started receiving translation and interpreting services through this private contract, countless complaints from barristers, translators and judges all over England and Wales have been recorded concerning cases in which interpreters had not appeared in court, did not speak the necessary language or did not have the required legal knowledge to interpret effectively during court proceedings (Bell 2012: online).

With time, as it is pointed out in the report from the British National Audit Office, actions on the part of both the Ministry and its language services supplier have improved the conditions under which the new contract operates. In any case, there is still much to do to ensure that the new system functions in a way that reflects a return to previous standards. Consequently, it is necessary to work on all these items in order to foster improvements regarding this circumstance. We consider that is fundamental to properly evaluate the skills of professionals working in this field against certain accreditation criteria formally established. In the same way, compliance with professional ethics is also a prerequisite for the praxis of court and legal interpreting. Finally, development and membership of professional associations is an additional must.

Secondly, we can conclude that there is a tendency towards the outsourcing of services in the language industry. We believe that this trend responds to the ambitious attempts from the Administration to reduce costs. However, as it has been investigated, there are numerous indications that this can undermine quality. As such, we have documented the outsourcing process for court interpreting services within the Ministry of Justice (MoJ) in the United Kingdom. This responds to the hypothesis that by using intermediaries to obtain interpreting services from professionals, there are necessary elements in the outsourcing process to guarantee a certain standard of quality. In the absence of some or all of these elements, quality is very possibly at stake.

The research carried out to provide an account of the procurement and implementation processes for the Moj's new language services system has allowed us to determine that the flaws in the outsourcing contract had resulted in an efficient performance of the system. However, the objective of this article was not to measure the quality of the interpreting services provided to the MoJ through its 
outsourcing company. There is therefore a need for further studies which explore in detail the quality features of the interpretations being carried out under the terms and conditions of this contract. To do so, the analysis of such contract carried out in this paper, which points out its weakness and potentials threats to quality, can prove useful in distinguishing what aspects to look at.

\section{Bibliography}

ABRIL, M. I. (2008). “La Interpretación en los Servicios Públicos: Caracterización como género, contextualización y modelos de formación. Hacia unas bases para el diseño curricular". Tesis doctoral. Universidad de Granada, http://hera.ugr.es/tesisugr/16235320.pdf. [Last visit: 28th October 20I5].

AllC, International Association of Conference Interpreters. https://aiic.net/ [Last visit: 29th October 2015]

BBC News (2013) "Court contract handling by Ministry of Justice a shambles". http://www.bbc.co.uk/news/uk-213477I8. [Last visit: 28th October 20I5]

BELL, S. (20I2). "Court chaos follows interpreter change" in BBC News, http://www.bbc.co.uk/news/uk-17009| I5. [Last visit: 28th October 20I5]

CARR, S. E., ROBERTS, R. P. et al. (1997). The Critical Link: Interpreters in the Community. Papers from the $I^{\text {st }}$ International Conference on interpreting in legal, health and social service settings. Amsterdam: John Benjamins, 21.

"Code of Professional Conduct" (2016), National Register of Public Service Interpreters, last accessed January 24, http://www.nrpsi.org.uk/for-clientsof-interpreters/code-of-professional-conduct.html. [Last visit: 24th October 20I5].

Collados, A. and DANIEL G., La qualité de l'interprétation de conference: une synthèse des travaux empiriques (Hong Kong: Quaille, 200I), 3I2-326.

Collados Aís, A. et al. (2002) "La qualité de l'interprétation de conférence: une synthèse des travaux empiriques" in Cai (Ed.) Recent Research into interpreting: new methods, concepts and trends, Hong Kong: Quaille. 312-326.

D'HAYER, D. (20I2). "Public Service Interpreting and Translation: Moving Towards a (Virtual) Community of Practice”, Meta: journal des traducteurs , 57: 235247.

(2015). "Diploma in Public Service Interpreting: Handbook for Candidates", Chartered Institute of Linguistics, last updated October, https://www.ciol.org.uk/images/Qualifications/DPSI/DPSI\%20Handbook\%20 Oct-I5.pdf. [Last visit: 25th October 20I5].

Eurlex Dictionary, "The Schengen area and cooperation", Last updated August 3, 2009 , http://eur-lex.europa.eu/legalcontent/EN/TXT/?uri=URISERV\%3AI33020. [Last visit: 27th October 20I5]. 
European Parliament. (2010). "European Directive 2010/64/EU of the European Parliament and of the Council on the right to interpretation and translation in criminal proceedings" in Official Journal of the European Union, http://eulita.eu/sites/default/files/directive_en.pdf. [Last visit: 28th October 2015].

European Court of Human Rights. (1950). "European Convention for the Protection of Human Rights and Fundamental Freedoms", http://www.echr.coe.int/Documents/Convention_ENG.pdf. [Last visit: 28th October 2015].

Justice Committee. (20/3). (C) Parliamentary cop. "Government Response to the Justice Committee's Sixt Report of Session 2012-13", Ministry of Justice, . http://www.publications.parliament.uk/pa/cm2012/3/cmselect/cmjust/645/6 45vw05.htm. [Last visit: 28th October 2015].

MARTIN, A. et al. (200I). "Los límites difusos del papel de la interpretación social" en Valero Garcés. C. y G. M. Bares (Eds.) Traducción e interpretación en los servicios públicos: nuevas necesidades para nuevas realidades. Alcalá: Universidad de Alcalá. 57-62.

MAteo, M. C. (2004). "La interpretación social: hacia el reconocimiento de la profesión" en Jornades de Foment de la Investigació. Universitat Jaume I. http://repositori.uji.es/xmlui/bitstream/handle/10234/79/27/forum_2004_4 6.pdf?sequence $=$ I. [Last visit: 27 th October 2015].

MIKKELSON, H. (1999). "The professionalization of community interpreting" in Global Vision: Proceedings of the 37th Annual Conference of the American Translators Association. http://aiic.net/page//546/the-professionalization-ofcommunity-interpreting/lang/l. [Last visit: 26th October 20/4].

Ministry of Justice. (20I3). "Statistics on the use of language services in courts and tribunals", Statistical bulletin. https://www.gov.uk/government/uploads/system/uploads/attachment_data/f ile/ I7704I/language-service-stats-hmcts-jan I I-jan /2.pdf. [Last visit: 28th October 2014].

Ministry of Justice. (20/3b). "Government Response to the Justice Committee's Sixt Report of Session 2012-13". https://www.gov.uk/government/uploads/system/uploads/attachment_data/f ile/192487/jsc-report-interpreting.pdf. [Last visit: 28th October 2015].

National Audit Office. (20I2). "The Ministry of Justice's language services contract" http://www.nao.org.uk/wp-

content/uploads/2012/09/12/3_Mo]_Language_services.pdf. [Last visit: 25th October 2015].

National Register of Public Service Interpreters (NRPSI) http://www.nrpsi.org.uk/pdf/CriteriaforEntry.pdf. [Last visit: 29th October 2015]. 
ORTEGA, J. M. (2010). Interpretar para la Justicia. Granada: Comares.

- (2013). "La intérprete no solo tradujo lo que le vino en gana, sino que respondió ella a las preguntas que los abogados le realizaban al testigo: requisitos de calidad en la subcontratación de servicios de interpretación judicial y policial en España”, Sendebar, 24: 9-42.

PÖCHHACKER, F. (200I). "Quality Assessment in Conference and Community Interpreting”, Meta: journal des traducteurs, 46 (200I): 4I 0-425.

"The Ministry of Justice's language services contract", National Audit Office, September 10, 2012. https://www.nao.org.uk/report/the-ministry-ofjustices-language-services-contract/ [Last visit: 27th October 2015].

RUTHERFORD, A. (20I4) " $€ 30,000$ : cost of rape trial that was abandoned after one day" in Belfast Telegraph, http://www.belfasttelegraph.co.uk/news/localnational/northern-ireland/30000-cost-of-rape-trial-that-was-abandonedafter-one-day-29994644.html. [Last visit: 27th October 20I5].

SALES, D. (2007). "Awareness in an immigrant-receiving society: Intercultural mediation and translation/interpretation in public services", in Discourse and International Relations, ed. U. Dagmar Scheu Lottgen and José Saura Sánchez, Germany: Peter Lang. 279-302.

Statistics on the use of language services in courts and tribunals", Statistical bulletin, 30 January 2012 to 31 January 20I3", Ministry of Justice, March 28, 20I3: 7. 
